A.-M. Aas • I. Seljeflot • P. A. Torjesen •

L. M. Diep · P. M. Thorsby $\cdot$ K. I. Birkeland

\title{
Blood glucose lowering by means of lifestyle intervention has different effects on adipokines as compared with insulin treatment in subjects with type 2 diabetes
}

Received: 3 October 2005 / Accepted: 14 January 2006 / Published online: 23 March 2006

C) Springer-Verlag 2006

\begin{abstract}
Aims/hypothesis: Adipokines may be important in mediating signals from adipocytes to insulin-sensitive tissue and vasculature. We studied the effect of different glucose-lowering therapies on serum levels of plasminogen activator inhibitor-1 (PAI-1), high-sensitivity Creactive protein (hs-CRP), TNF- $\alpha$, leptin, adiponectin
\end{abstract}

Electronic Supplementary Material Supplementary material on this article is available at http://dx.doi.org/10.1007/s00125-0060205-8

A.-M. Aas $(\bowtie)$

Department of Nutrition and Dietetics,

Aker University Hospital,

Trondheimsveien 235,

0514 Oslo, Norway

e-mail: anne-marie.aas@akersykehus.no

Tel.: +47-22-894641

Fax: +47-23-033057

A.-M. Aas · P. A. Torjesen •

P. M. Thorsby · K. I. Birkeland

Aker/Ullevål Diabetes Research Centre,

Oslo, Norway

I. Seljeflot

Centre for Clinical Research,

Ullevål University Hospital,

Oslo, Norway

P. A. Torjesen · P. M. Thorsby · K. I. Birkeland

Hormone Laboratory,

Aker University Hospital,

Oslo, Norway

L. M. Diep

Research Centre,

Aker University Hospital,

Oslo, Norway

K. I. Birkeland

Faculty Division,

Aker University Hospital, University of Oslo,

Oslo, Norway and ghrelin in patients with type 2 diabetes. Subjects and methods: Twenty-eight patients with poorly controlled type 2 diabetes who were receiving oral hypoglycaemic agents were allocated to one of the following groups, and treated for 1 year: (1) lifestyle intervention (L); (2) insulin treatment $(\mathrm{I})$; and (3) combined treatment $(\mathrm{L}+\mathrm{I})$. Results: Similar improvements in glycaemic control occurred in all three groups. There was a reduction in body weight of $3.0 \mathrm{~kg}$ (median) $(95 \% \mathrm{CI}-5.9$ to -2.0$)$ in group L, whereas in groups $\mathrm{L}+\mathrm{I}$ and I body weight increased by $3.5 \mathrm{~kg}(95 \%$ CI 1.5-4.9) and $4.9 \mathrm{~kg}(95 \% \mathrm{CI}$ -3.1 to 8.2 ), respectively. By trend analyses, group L had reduced levels of PAI-1 $(p=0.002)$, hs-CRP $(p<0.0001)$ and TNF- $\alpha(p=0.006)$, while no significant changes were observed in the levels of leptin or adiponectin. In group I, the median levels of PAI-1 $(p=0.008)$, TNF- $\alpha(p=0.058)$ and leptin $(p=0.004)$ increased. In the $\mathrm{L}+\mathrm{I}$ group there was a reduction in PAI- 1 levels $(p=0.014)$ and an increase in levels of leptin $(p<0.001)$. The differences in changes in the levels of PAI-1, hs-CRP, TNF- $\alpha$ and leptin between groups were also significant (all $p<0.01$ ). Conclusions/ interpretation: Improvement of glycaemic control through lifestyle intervention in type 2 diabetes had more beneficial effects on adipokine levels than when the same lowering of $\mathrm{HbA}_{1 \mathrm{c}}$ was achieved with insulin treatment.

Keywords Adiponectin - C-reactive protein - Diabetes mellitus type 2 - Exercise · Ghrelin - Inflammation · Leptin - Plasminogen activator inhibitor-1 - TNF-alpha · Weight loss

Abbreviations CRP: C-reactive protein - ESM: Electronic Supplementary Material · HOMA-B: homeostasis model assessment of beta cell function . HOMA-S: homeostasis model assessment of insulin sensitivity - hs-CRP: high-sensitivity C-reactive protein . $\mathrm{I}$ : insulin (treatment) $\cdot \mathrm{L}$ : lifestyle (intervention) $\cdot \mathrm{L}+\mathrm{I}$ : combined lifestyle intervention and insulin treatment . OHA: oral hypoglycaemic agent - PAI-I: plasminogen activator inhibitor- $1 \cdot \mathrm{SU}$ : sulfonylurea 


\section{Introduction}

Several adipokines have been identified that relate inflammation and impaired fibrinolysis to diabetes, obesity and cardiovascular disease $[1,2]$. Insulin resistance has been considered central in the pathophysiological processes behind the metabolic syndrome; however, recent literature suggests that inflammation, secondary to genetic predisposition and modified by environmental stimuli, may be a probable proximate cause for the development of insulin resistance [3].

Population studies have shown strong associations between indices of inflammation, abnormal lipid and carbohydrate metabolism, obesity and insulin resistance [4-8]. In a cross-sectional study of 822 young men and women [5], obesity was independently related to Creactive protein (CRP), with a $3-7 \%$ increase in mean CRP levels for each unit $\left(\mathrm{kg} / \mathrm{m}^{2}\right)$ increase in BMI. Several adipokines act either as independent risk factors, or as combined risk factors. A strong positive correlation between both circulating and adipose tissue levels of TNF- $\alpha$, leptin and high-sensitivity CRP (hs-CRP) levels has been reported, but these correlations disappeared when adjusted for fat mass [8]. The authors concluded that there is a strong relationship between adipocytokines and inflammatory markers, suggesting that cytokines secreted by adipose tissue in obese subjects play a role in the increased secretion of inflammatory proteins by the liver. Subclinical inflammation has been shown to precede the onset of type 2 diabetes [9-12] and increase the risk of CHD [13-16].

Long-term insulin treatment of type 2 diabetic subjects is typically accompanied by a weight gain of $4-5 \mathrm{~kg}$ during the first year of treatment [17-19]. This side-effect might counteract several of the positive effects of the insulinmediated decrease in plasma levels of glucose, and this may be one of the reasons why insulin therapy has not proven effective in reducing morbidity or mortality of cardiovascular disease in type 2 diabetes [20].

In patients with type 2 diabetes, lifestyle intervention has shown beneficial effects on traditional risk factors for cardiovascular disease, such as plasma glucose, blood lipids and blood pressure, although the effect may be modest and transient [21-31]. The evidence for an association between glycaemic control and systemic inflammation in subjects with diabetes seems conflicting [32-35]. The purpose of the present study was to determine the effect on adipokines of lowering blood glucose through lifestyle intervention or through insulin therapy in initially poorly controlled type 2 diabetic patients.

\section{Subjects and methods}

Details of study design, methods and major outcomes of the study on blood glucose and lipid levels and body composition have previously been published [31]. The analyses we report herein were conducted to further elucidate the hypothesis generated by the primary results of the study.

\section{Subjects}

The patients had a clinical diagnosis of type 2 diabetes and a fasting C-peptide concentration $>0.7 \mathrm{nmol} / 1$ and were anti-GAD negative. Eligible subjects completed a consent form approved by the regional ethics committee and were randomly allocated to one of the following three intervention groups: (1) lifestyle intervention (L), (2) insulin treatment (I) and (3) combined treatment (L+I). Ten of the 38 randomised subjects were not able to complete the study

Table 1 Baseline characteristics of the study population

\begin{tabular}{|c|c|c|c|c|c|}
\hline Characteristic & $\begin{array}{l}\text { All randomised }(n=28 \\
[16 \text { males } / 12 \text { females }])\end{array}$ & $\begin{array}{l}\text { Lifestyle group }(n=9 \\
[6 \text { males } / 3 \text { females }])\end{array}$ & $\begin{array}{l}\text { Lifestyle+insulin }(n=10 \\
[4 \text { males } / 6 \text { females }])\end{array}$ & $\begin{array}{l}\text { Insulin group }(n=9 \\
[6 \text { males } / 3 \text { females }])\end{array}$ & $\begin{array}{l}p \text { value } \\
\text { between } \\
\text { groups }\end{array}$ \\
\hline Age (years) & $59(52-66)$ & $59(45-67)$ & $62(49-74)$ & $53(39-66)$ & 0.44 \\
\hline $\begin{array}{l}\text { Diabetes duration } \\
\text { (years) }\end{array}$ & $6(4-8)$ & $8(3-9)$ & $6(3-9)$ & $7(2-11)$ & 0.67 \\
\hline $\mathrm{HbA}_{1 \mathrm{c}}(\%)$ & $9.2(8.3-9.8)$ & $8.3(7.8-9.2)$ & $9.2(7.7-9.7)$ & $9.8(7.9-10.1)$ & 0.13 \\
\hline HOMA-B (\%) & $48.1(31.3-56.2)$ & $49.6(27.0-61.1)$ & $42.9(24.8-83.5)$ & $46.5(24.9-55.0)$ & 0.99 \\
\hline HOMA-S (\%) & $30.3(24.0-35.4)$ & $29.6(22.8-35.9)$ & $34.3(23.149 .8)$ & $24.3(16.2-34.3)$ & 0.33 \\
\hline $\begin{array}{l}\text { Total cholesterol } \\
(\mathrm{mmol} / \mathrm{l})\end{array}$ & $5.6(4.9-6.0)$ & $5.5(4.1-5.6)$ & $5.5(4.2-6.0)$ & $6.1(4.6-6.7)$ & 0.20 \\
\hline $\begin{array}{l}\text { HDL cholesterol } \\
(\mathrm{mmol} / \mathrm{l})\end{array}$ & $1.1(0.9-1.2)$ & $1.1(0.8-1.2)$ & $1.0(0.8-1.2)$ & $0.9(0.8-1.2)$ & 0.53 \\
\hline Triglycerides $(\mathrm{mmol} / \mathrm{l})$ & $1.8(1.7-2.2)$ & $1.7(1.2-2.4)$ & $1.8(1.2-2.7)$ & $2.2(1.5-4.9)$ & 0.32 \\
\hline $\begin{array}{l}\text { BP, systolic/diastolic } \\
(\mathrm{mmHg})\end{array}$ & $\begin{array}{l}148 / 90(138-156) / \\
(84-90)\end{array}$ & $\begin{array}{l}150 / 90(122-156) / \\
(76-90)\end{array}$ & $\begin{array}{l}143 / 90(137-158) / \\
(73-94)\end{array}$ & $\begin{array}{l}160 / 90(120-169) / \\
(77-96)\end{array}$ & $0.80 / 0.70$ \\
\hline
\end{tabular}

Values are medians (approximate $95 \%$ bootstrapped CIs) 
due to non-compliance (six subjects) or illness interfering with participation in the lifestyle intervention program (four subjects). The dropout rates were similar in the three treatment groups. The subjects who did not complete the study did not differ in changes in weight and $\mathrm{HbA}_{1 \mathrm{c}}$ during the run-in period, age or duration of diabetes. Since the purpose of this particular study was to investigate the effect of the different treatment options on adipokines, only the subjects who completed the study per protocol were included. The current analyses are made on fasting blood samples collected every third month from the 28 patients who completed the study: nine, ten and nine in the L, L+I and I groups, respectively. The baseline characteristics of the subjects are given in Table 1. Before entering the study all subjects were treated with maximal tolerated doses of sulfonylurea (SU) and metformin and the blood levels of $\mathrm{HbA}_{1 \mathrm{c}}$ were $8.0-10.5 \%$.

\section{Interventions}

Subjects in group I and L+I received insulin treatment at the outpatient research clinic. Insulin treatment was started with two doses of $8 \mathrm{U} \mathrm{NPH}$ insulin per day, one in the morning and one at bedtime. The doses were increased one or two times weekly until treatment target was reached, and regular insulin was added if necessary. The treatment goal was $\mathrm{HbA}_{1 \mathrm{c}} \leq 7.5 \%$, fasting and pre-prandial plasma glucose $5-8 \mathrm{mmol} / \mathrm{l}$ and post-prandial plasma glucose $<10 \mathrm{mmol} / 1$ without hypoglycaemia.

The lifestyle intervention programme focused on diet and exercise changes that were expected to produce weight loss and to improve metabolic control. The participants were given dietary advice in 14 group sessions and two individual consultations. The exercise programme consisted of group-based exercise for $1 \mathrm{~h}$ twice a week. The activities given were aerobic and of moderate intensity and included group exercise classes, walking, ball games and swimming.

The patients in the two insulin-treated groups discontinued treatment with oral hypoglycaemic agents (OHAs) as they started insulin treatment. One person in group L reduced the dose of glibenclamide by $3.5 \mathrm{mg}$ and two subjects reduced the dose of metformin by $500 \mathrm{mg}$ during the study due to hypoglycaemic episodes. One person increased the metformin dose by $500 \mathrm{mg}$ because of worsening in the glycaemic control.

Lipid-lowering drugs were kept unchanged during the study period in all study participants. Two subjects had their antihypertensive therapy changed from alfa-methyldopa and mibefradil to lisinopril, and one subject reduced the dose of antihypertensives during the study period.

\section{Methods}

All patients underwent a clinical examination including measurements of body weight in light clothes to the nearest $0.5 \mathrm{~kg}$ and body height to the nearest $0.5 \mathrm{~cm}$. BMI was calculated by dividing body weight in kilograms by height in metres squared. Body composition was estimated at baseline and at 12 months by dual-energy X-ray absorptiometry scanning (DPX-1; Lunar Radiation, Madison, WI, USA).

Blood samples were analysed for plasma glucose with the glucose oxidase method using a Glucose Analyzer II (Beckman Instruments, Fullerton, CA, USA) and $\mathrm{HbA}_{1 \mathrm{c}}$ using the method Variant (Bio-Rad, Richmond, CA, USA; normal reference range 4.1-6.4\%). Serum was separated and either analysed within $24 \mathrm{~h}$ or frozen at $-40^{\circ} \mathrm{C}$ for later analysis. An ELISA method was used for determination of TNF- $\alpha$ in serum (High Sensitivity Assay from R\&D Systems Europe, Abingdon, UK). The inter-assay CV was $8.5 \%$. Serum-levels of hs-CRP were also determined by an ELISA method from DRG Instruments, Marburg, Germany (inter-assay CV 6.8\%). Active plasminogen activator inhibitor-1 (PAI-1) was determined in citrate-plasma amidolytically, with a commercially available kit (SpectrolyseTM/pL; Biopool, Umeå, Sweden; inter-assay CV 4.8\%). The serum levels of insulin, ghrelin (total), adiponectin and leptin were measured with RIA kits from Linco Research, Inc. (St Charles, MO, USA). C-peptide levels were determined on Immulite 2000 (Diagnostic Products Corporation, Los Angeles, CA, USA). The interassay CVs were $7-18 \%$ for these hormone assays. Homeostasis model assessment of beta cell function (HOMA-B) and insulin sensitivity (HOMA-S) were estimated from fasting values of plasma glucose and serum C-peptide using a computer program kindly provided by J. C. Levy (Radcliffe Infirmary, Oxford, UK) [36].

\section{Statistical methods}

Medians (with approximate 95\% bootstrapped CIs) are used as measurements of central tendency, if not stated otherwise. To test the significance of changes from baseline to the end of the intervention within each treatment group, the Wilcoxon signed rank test was used and differences between treatment groups were compared by the use of the Kruskal-Wallis test. In the case of significant differences between groups, the Mann-Whitney test was used to find which groups differed. To test whether the trend (the data of all time-points included) was the same in the three treatment groups we used a linear mixed model. A linear mixed model was also used to test if there was a significant trend within the group during the intervention. To test whether the changes in body weight and $\mathrm{HbA}_{1 \mathrm{c}}$ confounded the trends observed in the adipokines, we did additional trend analysis with changes in $\mathrm{BMI}$ and $\mathrm{HbA}_{1 \mathrm{c}}$ and baseline BMI added as covariates in the model. Spearman's coefficient of correlation was calculated to test correlations between variables. Two-sided $p$ values less than 0.05 were considered statistically significant. The approximate $95 \%$ CIs for estimated median values were carried out in the statistical software S-plus 6.2 for Windows (Insightful, Seattle, WA, USA) using bootstrap 
and linear interpolation methods. Otherwise, statistical analyses were performed with SPSS 12.0 (SPSS, Chicago, IL, USA).

\section{Results}

There were no significant differences between groups in baseline characteristics of the patients (Table 1). The median $(95 \% \mathrm{CI})$ levels of $\mathrm{HbA}_{1 \mathrm{c}}$ were reduced in all the treatment groups, by $-1.2(-1.3,-0.4),-1.0(-2.3,-0.5)$ and $-1.5(-2.9,-0.1) \%$ in groups $\mathrm{L}, \mathrm{L}+\mathrm{I}$ and $\mathrm{I}$, respectively, with no significant difference in the reduction between the groups $(p=0.74)$. In group $\mathrm{L}$ weight was reduced by $3.0(-5.9,-2.0) \mathrm{kg}$, whereas in group $\mathrm{L}+\mathrm{I}$ weight increased by $3.5(1.5,4.9) \mathrm{kg}$ and in group I there was a non-significant trend toward weight increase by 4.9 $(-3.1,8.2) \mathrm{kg}(p=0.004$ between groups). Baseline levels of anthropometric parameters and adipokines and changes observed between start and 12 months are given in Table 2 . The levels of adipokines and anthropometric measurements were not different between the groups, except for levels of TNF- $\alpha$, which were significantly higher in group $\mathrm{L}$ than in the two other groups $(p=0.04)$. There was a significant difference between the changes in BMI and body fat between the three groups, as BMI and body fat was reduced in group L, increased significantly in group $\mathrm{L}+\mathrm{I}$ and tended to increase also in group I. The changes observed in PAI-1, hs-CRP and leptin differed significantly between the groups. The median level of PAI-1 was significantly reduced in groups $\mathrm{L}$ and $\mathrm{L}+\mathrm{I}$ and remained unchanged in group I. The median level of hs-CRP was significantly reduced in group L and remained unchanged in groups $\mathrm{L}+\mathrm{I}$ and I, while leptin levels tended to decrease in the lifestyle group and increased significantly in both the insulin-treated groups. The levels of adiponectin and ghrelin did not change significantly during the study in any of the groups, and there were no differences observed between the groups.

We then performed trend analyses including all the values from each three-monthly measurement in the model (Fig. 1, Table 3) and we performed the analyses again for the adipokines after adjustments for differences in baseline levels of BMI and for changes in BMI and $\mathrm{HbA}_{1 \mathrm{c}}$ during the study (Table 3 and Electronic Supplementary Material [ESM] Table 1). The trend analysis confirmed a significant difference in weight changes during the study between groups (Fig. 1b). The serum levels of PAI-1 decreased in

Table 2 Baseline values and changes in anthropometric measurements and adipokines

\begin{tabular}{|c|c|c|c|c|}
\hline Parameter & Lifestyle group $(n=9)$ & Lifestyle+insulin $(n=10)$ & Insulin group $(n=9)$ & $p$ value \\
\hline Prestudy & $29.8(26.7-34.5)$ & $31.1(28.5-35.8)$ & $30.0(25.8-31.0)$ & 0.48 \\
\hline \multicolumn{5}{|c|}{ Body fat (kg) } \\
\hline Prestudy & $31.4(22.6-43.4)$ & $30.6(26.2-34.8)$ & $26.9(21.9-33.9)$ & 0.54 \\
\hline Prestudy & $30.3(20.7-41.0)$ & $29.7(16.6-47.3)$ & $26.3(12.0-36.6)$ & 0.56 \\
\hline$\Delta 1$ year & $-15.2(-21.9 \text { to }-5.0)^{\mathrm{b}}$ & $-9.4(-16.9 \text { to }-3.1)^{\mathrm{b}}$ & $6.5(-16.5$ to 21.9$)$ & $0.022^{\mathrm{d}, \mathrm{e}}$ \\
\hline \multicolumn{5}{|c|}{ hs-CRP (mg/l) } \\
\hline Prestudy & $6.0(3.2-12.4)$ & $3.9(2.5-8.4)$ & $3.4(2.5-7.3)$ & 0.37 \\
\hline$\Delta 1$ year & $-3.3(-9.3 \text { to }-0.5)^{\mathrm{a}}$ & $-0.1(-0.4$ to 0.5$)$ & $0.8(-1.5$ to 1.2$)$ & $0.009^{\mathrm{c}, \mathrm{d}}$ \\
\hline \multicolumn{5}{|c|}{$\mathrm{TNF}-\alpha(\mathrm{pg} / \mathrm{ml})$} \\
\hline Prestudy & $675(360-1$ to 310$)$ & $604(418-1$ to021) & $650(394-957)$ & 0.81 \\
\hline$\Delta 1$ year & $-73(-294$ to -15$)$ & $439(184 \text { to } 840)^{\mathrm{b}}$ & $198(19 \text { to } 380)^{\mathrm{a}}$ & $0.002^{\mathrm{c}, \mathrm{d}}$ \\
\hline \multicolumn{5}{|c|}{ Adiponectin $(\mu \mathrm{g} / \mathrm{ml})$} \\
\hline Prestudy & $16.1(8.0-21.3)$ & $13.2(7.0-27.4)$ & $18.3(15.0-30.6)$ & 0.34 \\
\hline$\Delta 1$ year & $-1.4(-3.8$ to 0.0$)$ & $0.1(-3.8$ to 1.6$)$ & $-1.1(-10.7$ to 1.2$)$ & 0.62 \\
\hline \multicolumn{5}{|c|}{ Ghrelin (pg/ml) } \\
\hline Prestudy & $1856(891-2,607)$ & $1301(890-2,042)$ & $1106(933-1,289)$ & 0.31 \\
\hline$\Delta 1$ year & $-428(-792$ to 148$)$ & $63(-20$ to 130$)$ & $-7(-559$ to 22$)$ & 0.17 \\
\hline
\end{tabular}

Values are medians (approximate 95\% bootstrapped CIs)

${ }^{a} p<0.05$ for within-group changes

${ }^{\mathrm{b}} p<0.01$ for within-group changes

${ }^{c} p<0.05$ between lifestyle group and lifestyle+insulin group

$\mathrm{d}_{p}<0.05$ between lifestyle group and insulin group

${ }^{\mathrm{e}} p<0.05$ between lifestyle + insulin group and insulin group 
the two lifestyle intervention groups and increased in group I (Fig. 1c). The difference in trend between groups was significant $(p<0.001$, Table 3$)$. The trend analysis also showed a significant reduction in the hs-CRP and TNF- $\alpha$ levels in group L, while there was no consistent change in group $\mathrm{L}+\mathrm{I}$. Group I showed a non-significant tendency to increase in TNF- $\alpha$ levels $(p=0.058)$, but no change in hs-CRP levels (Fig. 1d,e). These differences in trends between group L and the two insulin-treated groups were significant for both hs-CRP and TNF- $\alpha$.

The changes in leptin levels were significantly different between the groups also by trend analysis $(p<0.0001)$. The increase in leptin levels was evident already after 3 months of insulin treatment, while an increase in weight was observed from 6 months and beyond (Fig. 1b,f). We did not observe any consistent changes in the levels of adiponectin in any of the treatment groups during the intervention year.
Fig. 1 Mean $( \pm 1$ SE) changes in (a) $\mathrm{HbA}_{1 \mathrm{c}}$, (b) body weight, (c) PAI-1, (d) hs-CRP, (e) TNF- $\alpha$ and (f) leptin during the intervention year in the lifestyle intervention (L) group (solid squares), the lifestyle + insulin $(\mathrm{L}+\mathrm{I})$ group (asterisks) and the insulin (I) group (open squares). $†$ Significant difference in trend between group $\mathrm{L}$ and group L+I and I. \#Significant difference in trend between group I and group L and L+I a

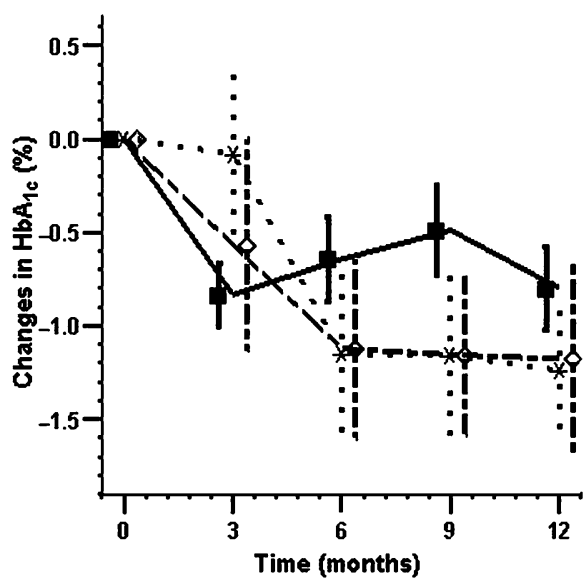

C

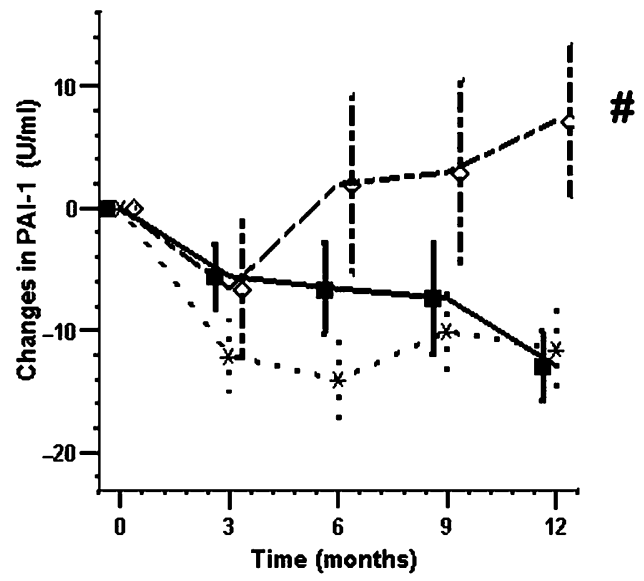

e

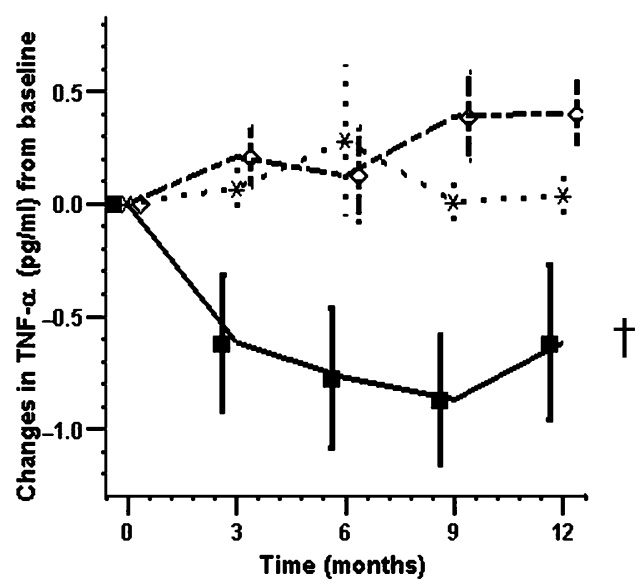

b

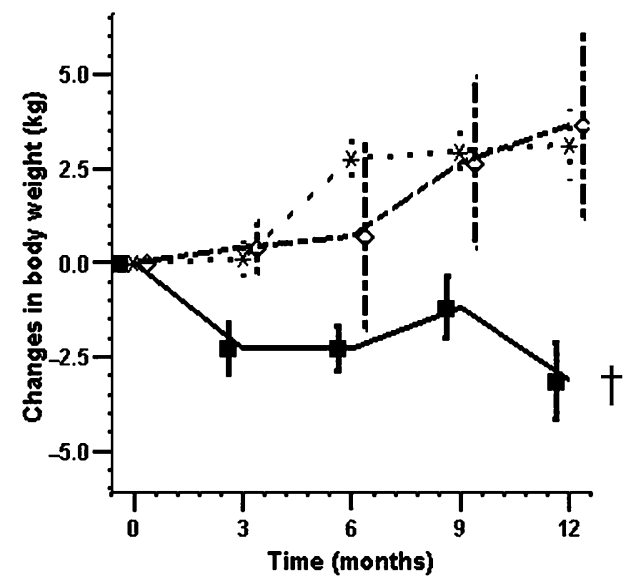

d

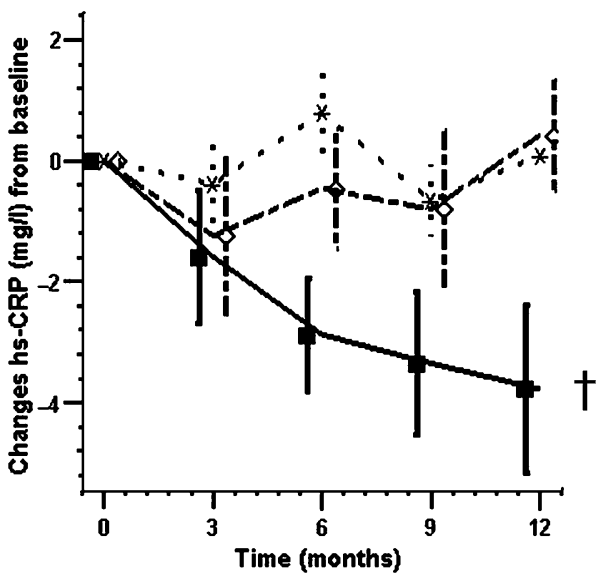

f

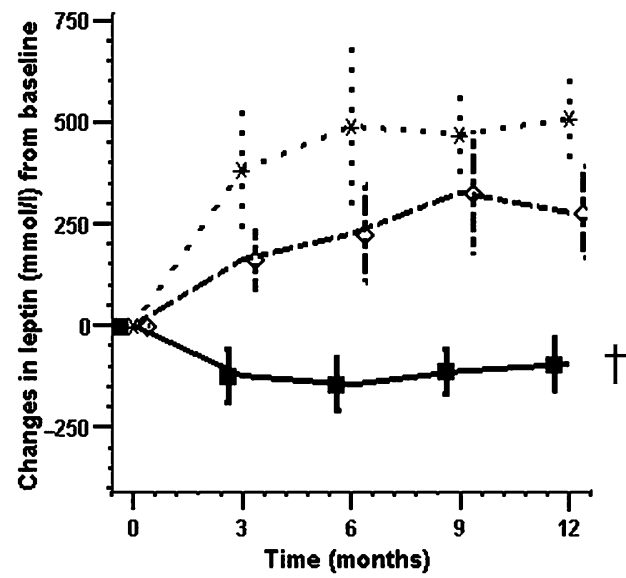


Table 3 Trend analyses of adipokines within and between treatment groups with adjustments for $\Delta \mathrm{BMI}$

\begin{tabular}{|c|c|c|c|c|c|c|}
\hline Parameter & $\begin{array}{l}\text { Trend within-group } \beta \\
\text { value }(95 \% \mathrm{CI})\end{array}$ & $\begin{array}{l}p \text { value } \\
\text { within-group } \\
\text { difference }\end{array}$ & $\begin{array}{l}p \text { value } \\
\text { between- } \\
\text { group } \\
\text { differences }\end{array}$ & $\begin{array}{l}\text { Adjusted }{ }^{\mathrm{a}} \text { trend within- } \\
\text { group } \beta \text { value }(95 \% \mathrm{CI})\end{array}$ & $\begin{array}{l}\text { Adjusted }^{\mathrm{a}} p \text { value } \\
\text { within-group } \\
\text { difference }\end{array}$ & $\begin{array}{l}\text { Adjusted }^{\mathrm{a}} p \text { value } \\
\text { between-group } \\
\text { differences }\end{array}$ \\
\hline \multicolumn{7}{|l|}{$\begin{array}{l}\text { PAI-1 } \\
(\mathrm{U} / \mathrm{ml})\end{array}$} \\
\hline Lifestyle & $-0.92(-1.51$ to -0.33$)$ & 0.002 & & $-0.94(-1.54$ to -0.34$)$ & 0.003 & \multirow[b]{2}{*}{$<0.001$} \\
\hline $\begin{array}{l}\text { Lifestyle+ } \\
\text { insulin }\end{array}$ & $-0.70(-1.26$ to -0.14$)$ & 0.014 & $<0.001$ & $-0.67(-1.26$ to -0.08$)$ & 0.027 & \\
\hline \multicolumn{7}{|l|}{$\begin{array}{l}\text { hs-CRP } \\
\text { (mg/l) }\end{array}$} \\
\hline Lifestyle & $-0.312(-0.455$ to -0.168$)$ & $<0.0001$ & & $-0.274(-0.416$ to -0.132$)$ & $<0.0001$ & \multirow[b]{2}{*}{0.043} \\
\hline $\begin{array}{l}\text { Lifestyle+ } \\
\text { insulin }\end{array}$ & $-0.003(-0.138$ to 0.132$)$ & 0.97 & $<0.001$ & $-0.072(-0.211$ to 0.068$)$ & 0.31 & \\
\hline \multicolumn{7}{|l|}{$\begin{array}{l}\mathrm{TNF}-\alpha \\
(\mathrm{pg} / \mathrm{ml})\end{array}$} \\
\hline Lifestyle & $-0.048(-0.082$ to -0.014$)$ & 0.006 & & $-0.042(-0.077$ to -0.008$)$ & 0.017 & \multirow[b]{2}{*}{0.040} \\
\hline $\begin{array}{l}\text { Lifestyle+ } \\
\text { insulin }\end{array}$ & $0.000(-0.032$ to 0.032$)$ & 0.98 & 0.005 & $-0.010(-0.044$ to 0.023$)$ & 0.54 & \\
\hline \multicolumn{7}{|l|}{$\begin{array}{l}\text { Leptin } \\
(\mathrm{mmol} / \mathrm{l})\end{array}$} \\
\hline Lifestyle & $-5.8(-21.1$ to 9.5$)$ & 0.45 & & $-0.4(-15.0$ to 14.2$)$ & 0.96 & \multirow[b]{2}{*}{0.043} \\
\hline $\begin{array}{l}\text { Lifestyle+ } \\
\text { insulin }\end{array}$ & $36.7(22.3-51.1)$ & $<0.001$ & $<0.0001$ & $26.6(12.2-41.0)$ & $<0.001$ & \\
\hline \multicolumn{7}{|l|}{$\begin{array}{l}\text { Adiponectin } \\
(\mu \mathrm{g} / \mathrm{ml})\end{array}$} \\
\hline Lifestyle & $-0.05(-0.30$ to 0.20$)$ & 0.70 & & $-0.13(-0.37$ to 0.11$)$ & 0.27 & \multirow[b]{2}{*}{0.11} \\
\hline $\begin{array}{l}\text { Lifestyle+ } \\
\text { insulin }\end{array}$ & $0.09(-0.14$ to 0.32$)$ & 0.44 & 0.59 & $0.24(0.01-0.47)$ & 0.040 & \\
\hline \multicolumn{7}{|l|}{$\begin{array}{l}\text { Ghrelin } \\
(\mathrm{pg} / \mathrm{ml})\end{array}$} \\
\hline Lifestyle & $-19.9(-35.6$ to -4.2$)$ & 0.013 & & $-22.0(-37.8$ to -6.2$)$ & 0.007 & \multirow{3}{*}{0.070} \\
\hline $\begin{array}{l}\text { Lifestyle+ } \\
\text { insulin }\end{array}$ & $0.9(-13.9$ to 15.7$)$ & 0.90 & 0.16 & $4.7(-10.8$ to 20.3$)$ & 0.55 & \\
\hline Insulin & $-10.0(-25.6$ to -5.6$)$ & 0.21 & & $-6.6(-22.7$ to 9.6$)$ & 0.42 & \\
\hline
\end{tabular}

$\beta$ values show mean change in adipokines for every month of the intervention

${ }^{a}$ Adjusted for changes in BMI from baseline to 12 months

There was a tendency towards a reduction in ghrelin levels in group L, although the difference between the groups was not significant.

When adjusted for changes in BMI during the intervention, the differences between the treatment groups regarding trends in hs-CRP, TNF- $\alpha$ and leptin, were less marked, but were still significant (Table 3 ). When change in BMI was added as a covariate in the mixed linear model, the $\beta$ values that show the effect of $\triangle B M I$ on the adipokines were $0.61(p=0.005)$ for hs-CRP, $0.10(p<0.05)$ for TNF- $\alpha$ and $90.9(p<0.001)$ for leptin. The difference in trend in PAI-1 between groups was not affected by the adjustment of changes in BMI $(\beta=-0.26, p=0.77)$. On the other hand, when the model was adjusted for BMI at baseline, there was a significant interaction between BMI and PAI-1 $(\beta=1.07, p=0.04$, ESM Table 1$)$, indicating a mean increase in the level of PAI-1 by $1.07 \mathrm{U} / \mathrm{ml}$ for $1 \mathrm{U}$ increase in baseline BMI. This shows that baseline BMI was important for changes in plasma levels of PAI-1 during the intervention even though changes in BMI were not. Adjustments for baseline BMI did not affect the significance of the effect of treatment group on changes in any of the other adipokines, and neither did adjustments for changes in $\mathrm{HbA}_{1 \mathrm{c}}$ (ESM Table 1). 
The importance of changes in body weight was confirmed by correlation analysis across treatment groups. The changes in body weight correlated with changes in hsCRP $(r=0.73, p<0.001)$, TNF- $\alpha(r=0.40, p=0.04)$ and leptin $(r=0.74, p<0.001)$. Changes in the level of hs-CRP correlated with changes in leptin $(r=0.63, p<0.001)$ and TNF- $\alpha(r=0.44, p=0.02)$ concentrations. There was also a correlation of borderline significance between changes in levels of TNF- $\alpha$ and leptin $(r=0.34, p=0.08)$. There were no significant correlations between changes in $\mathrm{HbA}_{1 \mathrm{c}}$ and changes in any of the adipokines.

\section{Discussion}

In this study of patients with type 2 diabetes, lifestyle intervention reduced levels of PAI-1, hs-CRP and TNF- $\alpha$, while insulin therapy increased the levels of PAI-1, TNF- $\alpha$ and leptin despite a similar blood-glucose-lowering effect. A considerable part of these effects was linked to the intervention's effect on body weight. Statistical adjustment for changes in BMI weakened the effect of treatment group on hs-CRP, TNF- $\alpha$ and leptin and showed that BMI change was an independent predictor for changes in the same adipokines during the intervention. These associations were confirmed by the close correlation between changes in body weight from baseline to 12 months and changes in hs-CRP, TNF- $\alpha$ and leptin in the same interval. Furthermore, in the ranges studied, the changes in the levels of adipokines were independent of the plasma glucose levels. In the group that received both lifestyle and insulin intervention, the levels of PAI-1 decreased despite an increase in body weight, indicating that lifestyle intervention can have a beneficial effect on PAI-1 beyond the changes in body weight. Another important finding is the considerable increase in leptin levels observed after the start of insulin treatment. Higher levels of leptin in insulin-treated type 2 diabetic subjects compared with patients on OHAs have previously been reported [37]. However, for the first time, we present longitudinal data that seem to indicate that the main increase in leptin levels precedes the main weight increase during chronic insulin treatment.

To the best of our knowledge, this is the first study that reports a direct, prospective comparison between lifestyle intervention and insulin treatment on the effect on important adipokines in type 2 diabetes. Our findings are mainly in accord with what could be expected from studies in non-diabetic individuals. Increased physical activity has shown beneficial effects on inflammatory markers in healthy individuals [38], in patients with chronic heart failure [39], and in patients with intermittent claudication [40]. Furthermore, in 180 patients with the metabolic syndrome following a two-year lifestyle intervention programme, $4 \mathrm{~kg}$ of weight reduction resulted in a $1.1 \mathrm{mg} / \mathrm{l}$ median reduction in hs-CRP levels [41]. The authors attributed their findings to the composition of the diet rather than to the energy balance and claimed that it was largely independent of the changes in body weight. Because the diet prescribed in our study was similar to the diet of their control group, the exercise part of the intervention may be responsible for the reductions in hsCRP and body weight in our lifestyle group. In a similar study of 60 obese women performed earlier by the same group [42], the lifestyle intervention group reduced body weight by $14 \mathrm{~kg}$ and obtained the same reduction in hsCRP $(1.1 \mathrm{mg} / \mathrm{l})$. However, in contrast to our findings an additional increase in the levels of adiponectin $(2.7 \mu \mathrm{g} / \mathrm{ml})$ was obtained. Recent studies have indicated that the most biological active form of adiponectin is the high and medium molecular weight adiponectin oligomers [43]. Our analysis does not quantify the content of the different forms of adiponectin and this may be the reason why we do not observe a significant interaction. In a trial comparing the effect of two low-fat diets differing in carbohydrate:protein ratio in obese subjects with hyperinsulinaemia, a weight reduction of $2.9-4.1 \%$ resulted in a significant reduction of CRP at week 68 in both intervention groups [44].

A possible confounding effect of other pharmacological agents than insulin in our study cannot be ruled out. Lipidlowering and antihypertensive therapies were largely kept unchanged during the study, except for a few individuals who changed antihypertensive therapy. The patients in the L group continued their tablet treatment with SU and metformin, while the participants randomised to insulin treatment were taken off OHAs. Two subjects had their doses of metformin reduced, one from 2,000 to $1,500 \mathrm{mg}$ /day and the other from 2,500 to $2,000 \mathrm{mg} / \mathrm{day}$, and one subject had the dose of glibenklamid reduced from 10.5 to $7 \mathrm{mg} /$ day, because of hypoglycaemic episodes resulting from the glucose-lowering effect of the achieved weight reduction and increased physical activity. In a study comparing insulin treatment in combination with either metformin or placebo [45], it was shown that metformin treatment was associated with a decrease in PAI-1 and other markers of endothelial dysfunction independently of changes in glycaemic control and body weight, without any effect on hs-CRP. Others have found that metformin treatment lowers both PAI-1 and CRP [46]. In our study, however, we found a decrease in PAI-1 both in the lifestyle intervention group that continued metformin treatment and in the group that stopped metformin and combined lifestyle intervention with insulin treatment. Other studies have consistently reported significantly decreased PAI-1 levels following regular exercise and there is ample evidence that weight reduction reduces PAI-1 and tissue-type plasminogen activator antigen levels in non-diabetic subjects [47]. Still there is a risk that stopping metformin in groups $\mathrm{L}+\mathrm{I}$ and $\mathrm{I}$ may have contributed to the differences between these groups and group $\mathrm{L}$ at the end of the study.

Decreased plasma levels of glucose might be expected to result in reduced transcription of the PAI-1 gene and increased fibrinolytic activity in vascular tissue [48]. In one study [49] insulin therapy decreased plasma PAI-1 activity in patients with type 2 diabetes without changes in glycaemic control. In another study [50] insulin therapy resulted in greater reduction in plasma PAI-1 concentrations than did SU therapy. Different insulin regimens, different effects on body weight or differences in the 
patient characteristics may contribute to explain the discrepant findings.

The mechanisms that regulate the levels of the different adipokines remain unclear. Synthesis of adipose tissue TNF- $\alpha$ and leptin could induce the production of hs-CRP, PAI-1 and other acute-phase reactants, thus contributing to the maintenance of a chronic low-grade inflammation state involved in the progression of obesity and its associated comorbidities. In a cross-sectional study [51] BMI, type 2 diabetes and adipose TNF- $\alpha$ mRNA levels were significant predictors of serum CRP levels. This is in line with our results, where change in BMI was an independent predictor of hs-CRP, TNF- $\alpha$ and leptin, and also the observed intercorrelations between changes in TNF- $\alpha$ and leptin and changes in hs-CRP.

The insulin-treated group did not reach target levels of $\mathrm{HbA}_{1 \mathrm{c}}$ and a more aggressive insulin treatment may have resulted in better glycaemic control and more favourable effects on the adipokines studied. On the other hand, the $\mathrm{L}$ group started out with a slightly lower $\mathrm{HbA}_{1 \mathrm{c}}$ level and at the end of the intervention year $\mathrm{HbA}_{1 \mathrm{c}}$ levels were similar in the intervention groups.

Despite the limited number of participants in our study our findings indicate that improved glycaemic control through lifestyle-induced weight loss in type 2 diabetes may be more beneficial than lowering of $\mathrm{HbA}_{1 \mathrm{c}}$ through insulin treatment. Given the importance of inflammatory and fibrinolytic processes in the pathogenesis of atherosclerotic vascular disease, our findings may contribute to an explanation of the marginal effects on cardiovascular outcomes in the intensively treated group in the UK Prospective Diabetes Study, where both SU and insulin treatments were accompanied by considerable weight increase. Thus lifestyle modification should be emphasised in the treatment of type 2 diabetes.

Acknowledgements We thank J. A. Falch and his staff at the Department of Medicine, Unit for Osteoporosis, Aker University Hospital for performing dual-energy X-ray absorptiometry scanning for estimation of body composition in all study participants. We would also like to thank the laboratory staff at the Hormone Laboratory at Aker University Hospital and Centre for Clinical Research at Ullevål Hospital for the analysis of the adipokines. The study was supported by research grants from the Norwegian Foundation for Health and Rehabilitation and The Norwegian Diabetes Association.

Duality of interest The authors are not aware of any duality of interest.

\section{References}

1. Lau DC, Dhillon B, Yan H, Szmitko PE, Verma S (2005) Adipokines: molecular links between obesity and atherosclerosis. Am J Physiol Heart Circ Physiol 288:2031-2041

2. Tataranni PA, Ortega E (2005) A burning question: does an adipokine-induced activation of the immune system mediate the effect of overnutrition on type 2 diabetes? Diabetes 54:917-927

3. Kereiakes DJ, Willerson JT (2003) Metabolic syndrome epidemic. Circulation 108:1552-1553
4. Juhan-Vague I, Alessi MC, Mavri A, Morange PE (2003) Plasminogen activator inhibitor-1, inflammation, obesity, insulin resistance and vascular risk. J Thromb Haemost $1: 1575-1579$

5. Williams MJA, Williams SM, Milne BJ, Hancox RJ, Poulton R (2004) Association between C-reactive protein, metabolic cardiovascular risk factors, obesity and oral contraceptive use in young adults. Int J Obes Relat Metab Disord 28:998-1003

6. Haffner SM (2003) Insulin resistance, inflammation, and the prediabetic state. Am J Cardiol 92:18-26

7. Yudkin JS, Stehouwer CDA, Emeis JJ, Coppack SW (1999) C-reactive protein in healthy subjects: associations with obesity, insulin resistance, and endothelial dysfunction: a potential role for cytokines originating from adipose tissue? Arterioscler Thromb Vasc Biol 19:972-978

8. Maachi M, Pieroni L, Bruckert E et al (2004) Systemic lowgrade inflammation is related to both circulating and adipose tissue TNFalpha, leptin and IL-6 levels in obese women. Int J Obes Relat Metab Disord 28:993-997

9. Pradhan AD, Manson JE, Rifai N, Buring JE, Ridker PM (2001) C-reactive protein, interleukin 6, and risk of developing type 2 diabetes mellitus. JAMA 286:327-334

10. Hanley AJ, Festa A, D'Agostino RB Jr et al (2004) Metabolic and inflammation variable clusters and prediction of type 2 diabetes: factor analysis using directly measured insulin sensitivity. Diabetes 53:1773-1781

11. Duncan BB, Schmidt MI, Pankow JS et al (2003) Low-grade systemic inflammation and the development of type 2 diabetes: The Atherosclerosis Risk in Communities Study. Diabetes 52:1799-1805

12. Laaksonen DE, Niskanen L, Nyyssonen K et al (2004) C-reactive protein and the development of the metabolic syndrome and diabetes in middle-aged men. Diabetologia 47:1402-1410

13. Pai JK, Pischon T, Ma J et al (2004) Inflammatory markers and the risk of coronary heart disease in men and women. N Engl J Med 351:2599-2610

14. Ridker PM, Cushman M, Stampfer MJ, Tracy RP, Hennekens $\mathrm{CH}$ (1997) Inflammation, aspirin, and the risk of cardiovascular disease in apparently healthy men. N Engl J Med 336:973-979

15. Wolk R, Berger P, Lennon RJ, Brilakis ES, Johnson BD, Somers VK (2004) Plasma leptin and prognosis in patients with established coronary atherosclerosis. J Am Coll Cardiol 44:1819-1824

16. Yudkin JS, Juhan-Vague I, Hawe E et al (2004) Low-grade inflammation may play a role in the etiology of the metabolic syndrome in patients with coronary heart disease: the HIFMECH study. Metabolism 53:852-857

17. Birkeland KI, Hanssen KF, Urdal P, Berg K, Vaaler S (1994) A long-term, randomized, comparative study of insulin versus sulfonylurea therapy in type 2 diabetes. J Intern Med 236:305-313

18. Yki-Jarvinen H, Ryysy L, Kauppila M et al (1997) Effect of obesity on the response to insulin therapy in noninsulindependent diabetes mellitus. J Clin Endocrinol Metab 82:4037-4043

19. Yki-Jarvinen H, Ryysy L, Nikkila K, Tulokas T, Vanamo R, Heikkila M (1999) Comparison of bedtime insulin regimens in patients with type 2 diabetes mellitus. A randomized, controlled trial. Ann Intern Med 130:389-396

20. UK Prospective Diabetes Study (UKPDS) Group (1998) Intensive blood-glucose control with sulphonylureas or insulin compared with conventional treatment and risk of complications in patients with type 2 diabetes (UKPDS 33). Lancet 352:837-853

21. Agurs-Collins TD, Kumanyika SK, Ten Have TR, AdamsCampbell LL (1997) A randomized controlled trial of weight reduction and exercise for diabetes management in older African-American subjects. Diabetes Care 20:1503-1511

22. Anderson JW, Brinkman-Kaplan V, Hamilton CC, Logan JE, Collins RW, Gustafson NJ (1994) Food-containing hypocaloric diets are as effective as liquid-supplement diets for obese individuals with NIDDM. Diabetes Care 17:602-604 
23. Brown SA, Upchurch S, Anding R, Winter M, Ramirez G (1996) Promoting weight loss in type II diabetes. Diabetes Care 19:613-624

24. Calle-Pascual AL, Rodriguez C, Camacho F et al (1992) Behaviour modification in obese subjects with type 2 diabetes mellitus. Diabetes Res Clin Pract 15:157-162

25. Low CC, Grossman EB, Gumbiner B (1996) Potentiation of effects of weight loss by monounsaturated fatty acids in obese NIDDM patients. Diabetes 45:569-575

26. Pascale RW, Wing RR, Blair EH, Harvey JR, Guare JC (1992) The effect of weight loss on change in waist-to-hip ratio in patients with type II diabetes. Int J Obes Relat Metab Disord 16:59-65

27. Pascale RW, Wing RR, Butler BA, Mullen M, Bononi P (1995) Effects of a behavioral weight loss program stressing calorie restriction versus calorie plus fat restriction in obese individuals with NIDDM or a family history of diabetes. Diabetes Care 18:1241-1248

28. Uusitupa M, Laitinen J, Siitonen O, Vanninen E, Pyorala K (1993) The maintenance of improved metabolic control after intensified diet therapy in recent type 2 diabetes. Diabetes Res Clin Pract 19:227-238

29. Wing RR, Blair E, Marcus M, Epstein LH, Harvey J (1994) Year-long weight loss treatment for obese patients with type II diabetes: does including an intermittent very-low-calorie diet improve outcome? Am J Med 97:354-362

30. Wolf AM, Conaway MR, Crowther JQ et al (2004) Translating lifestyle intervention to practice in obese patients with type 2 diabetes: Improving Control with Activity and Nutrition (ICAN) study. Diabetes Care 27:1570-1576

31. Aas AM, Bergstad I, Thorsby PM, Johannesen O, Solberg M, Birkeland KI (2005) An intensified lifestyle intervention programme may be superior to insulin treatment in poorly controlled type 2 diabetic patients on oral hypoglycaemic agents: results of a feasibility study. Diabet Med 22:316-322

32. King DE, Mainous AG III, Buchanan TA, Pearson WS (2003) C-reactive protein and glycemic control in adults with diabetes. Diabetes Care 26:1535-1539

33. Pickup JC (2004) Inflammation and activated innate immunity in the pathogenesis of type 2 diabetes. Diabetes Care 27:813-823

34. Gustavsson CG, Agardh CD (2004) Markers of inflammation in patients with coronary artery disease are also associated with glycosylated haemoglobin A1c within the normal range. Eur Heart J 25:2120-2124

35. Yudkin JS, Panahloo A, Stehouwer C et al (2000) The influence of improved glycaemic control with insulin and sulphonylureas on acute phase and endothelial markers in Type II diabetic subjects. Diabetologia 43:1099-1106

36. Matthews DR, Hosker JP, Rudenski AS, Naylor BA, Treacher DF, Turner RC (1985) Homeostasis model assessment: insulin resistance and beta-cell function from fasting plasma glucose and insulin concentrations in man. Diabetologia 28:412-419
37. Widjaja A, Stratton IM, Horn R, Holman RR, Turner R, Brabant G (1997) UKPDS 20: plasma leptin, obesity, and plasma insulin in type 2 diabetic subjects. J Clin Endocrinol Metab 82:654-657

38. Mattusch F, Dufaux B, Heine O, Mertens I, Rost R (2000) Reduction of the plasma concentration of C-reactive protein following nine months of endurance training. Int J Sports Med $21: 21-24$

39. Adamopoulos S, Parissis J, Kroupis C et al (2001) Physical training reduces peripheral markers of inflammation in patients with chronic heart failure. Eur Heart J 22:791-797

40. Tisi PV, Hulse M, Chulakadabba A, Gosling P, Shearman CP (1997) Exercise training for intermittent claudication: does it adversely affect biochemical markers of the exercise-induced inflammatory response? Eur J Vasc Endovasc Surg 14:344-350

41. Esposito K, Marfella R, Ciotola M et al (2004) Effect of a Mediterranean-style diet on endothelial dysfunction and markers of vascular inflammation in the metabolic syndrome: a randomized trial. JAMA 292:1440-1446

42. Esposito K, Pontillo A, Di PC et al (2003) Effect of weight loss and lifestyle changes on vascular inflammatory markers in obese women: a randomized trial. JAMA 289:1799-1804

43. Bobbert T, Rochlitz H, Wegewitz U et al (2005) Changes of adiponectin oligomer composition by moderate weight reduction. Diabetes 54:2712-2719

44. Brinkworth GD, Noakes M, Keogh JB, Luscombe ND, Wittert GA, Clifton PM (2004) Long-term effects of a high-protein, low-carbohydrate diet on weight control and cardiovascular risk markers in obese hyperinsulinemic subjects. Int J Obes Relat Metab Disord 28:661-670

45. Jaeger J, Kooy A, Lehert P et al (2005) Effects of shortterm treatment with metformin on markers of endothelial function and inflammatory activity in type 2 diabetes mellitus: a randomized, placebo-controlled trial. J Intern Med 257:100-109

46. Bailey CJ (2005) Treating insulin resistance in type 2 diabetes with metformin and thiazolidinediones. Diabetes Obes Metab 7:675-691

47. Lee KW, Lip GY (2003) Effects of lifestyle on hemostasis, fibrinolysis, and platelet reactivity: a systematic review. Arch Intern Med 163:2368-2392

48. Kohler HP, Grant PJ (2000) Plasminogen-activator inhibitor type 1 and coronary artery disease. $\mathrm{N}$ Engl J Med 342:1792-1801

49. Jain SK, Nagi DK, Slavin BM, Lumb PJ, Yudkin JS (1993) Insulin therapy in type 2 diabetic subjects suppresses plasminogen activator inhibitor (PAI-1) activity and proinsulin-like molecules independently of glycaemic control. Diabet Med 10:27-32

50. Panahloo A, Mohamed-Ali V, Andres C, Denver AE, Yudkin JS (1998) Effect of insulin versus sulfonylurea therapy on cardiovascular risk factors and fibrinolysis in type II diabetes. Metabolism 47:637-643

51. Bullo M, Garcia-Lorda P, Megias I, Salas-Salvado J (2003) Systemic inflammation, adipose tissue tumor necrosis factor, and leptin expression. Obes Res 11:525-531 